\title{
Money as an object of desire in Silesian folklore
}

\author{
Matgorzata Iżkowska
}

\begin{abstract}
Subjects to be explored in this paper include the role of money as a desirable item, the depictions of hidden treasures and the tricks of attaining them in folk stories, the social meanings of being poor or rich, stingy or generous - all in all, values and attitudes connected with money. The short description of the history of money and its social functions introduces the extraordinarily rich cultural reality connected with this phenomenon. Money is one of the most desirable possessions. A coin as an object of special features, the so-called inkluz, was treated as an amulet endowed with a magic power. The paper analyses Polish folk tales which very often evoke themes of desired treasures and extraordinary wealth, sought after and captured by the heroes. The folk tales use the topic of treasure to underline the personal features of a hero's character. Gaining money is possible only if the hero possesses positive character features, and evilness invariably deprives him/her of any hope of success.
\end{abstract}

Keywords: history of money, inkluz, magic properties of coins, devil's money, Polish treasure legends

Since men began using money as a form of payment, it became one of the subjects that people mostly sought after. The idea that everything can be bought using a piece of specially adapted metal meant that money and its purchasing power became the measure of success in life, the guarantee of personal convenience, and even the symbol of the social significance of the person. At the same time, the human desire for it brought about negative effects.

The myth of the golden rain that seduces Danae is supposed to reflect the omnipotence of wealth (Grimal 1987: 363). In ancient Greece, a god who was the personification of wealth appeared in its pantheon - Plutos (Kopaliński 2000: 601). In the comedies of Aristophanes Plutos is blind, so he is giving away his wealth to different people quite undeservedly. Since the beginnings of our 
culture, richness is associated with pride, selfishness and insensitivity to the suffering of others, and above all, with an insatiable greed.

The first coins appeared on Aegina, a Greek island located in the Saronic Gulf, at the end of the $7^{\text {th }}$ century BC (Kiersnowski 1962: 29), and on the obverse of coins there was the emblem of the city - a sea turtle. Almost at the same time money in the form of coins appeared in Lydia in Asia Minor, then at Corinth, Athens and soon in other Greek cities (ibid.: 29). The history of money dates back to the $4^{\text {th }}$ Century BC in the Roman Empire, and from there it spread throughout Western Europe. This invention made all commercial transactions easier, and was also convenient for many governments because of tax collection and payment of wages. Authors of "Wielka historia świata" ("Great history of the world") list money in the form of coins among the groundbreaking inventions of mankind, which has lasted to this day:

Jakież jednak imię dać owej epoce od końca Wieków Ciemnych po początek epoki klasycznej? Nazwa "archaiczna" jest mylaca. Mało epok w historii ludzkości może równać się wtaśnie $z$ ta pod względem ogromu i tempa zmian $w$ tak wielu dziedzinach. To czas gwattownych rewolucji, wiekopomnych odkryć, śmiatych pomystów. Oto kilka faktów kulturowych, które wtedy zaistniaty $i$ nadal sa obecne $w$ naszym życiu: pismo alfabetyczne, pieniadz $w$ formie monety, różne typy ustrojów politycznych (wśród nich demokracja), gtówne rodzaje literatury (epika, liryka, dramat), początki nauki i filozofii, nowe koncepcje religijne, ale i zalązki krytyki wierzeń, style architektury, regularnie odbywajace się igrzyska, zwtaszcza olimpijskie, skolonizowanie wybrzeży Morza Śródziemnego i Czarnego.

What name, however, to give to that era from the end of the Dark Ages to the early classical era? The name "archaic" is misleading. Few periods in history can be compared with this one in terms of magnitude and rate of change in so many areas. It is a time of violent revolutions, immortal discoveries, and bold ideas. Here are a few cultural facts which were then created, and still are present in our lives: alphabetical writing, money in the form of coins, various types of political regimes (including democracy), the main types of literature (epic, lyric poetry, drama), the beginnings of science and philosophy, new religious ideas as well as the beginnings of criticism of beliefs, styles of architecture, regularly held games (especially Olympic Games), colonisation of the shores of the Mediterranean and the Black Sea ${ }^{1}$ (Krawczuk 2005: 38).

1 All quotes in text have been translated by the author. 
Despite all the negative stereotypes associated with money, the invention was highly prized in the ancient world. A hero called Erichtonios, who invented the chariot pulled by four horses and who began the ceremony in honor of Athene the goddess, was famous also as the one who brought money to Athens (Grimal 1987: 88).

Money quickly spread in Europe and Asia, and its mobility is confirmed by archaeological sites, for instance in different places in Poland where coins often from very distant places have been found. Roman coins were quite popular in the lands of the Slavs and could be found today in places associated with the famous 'amber route' (bursztynowy szlak) (Kiersnowski 1962: 32). However, the Arab coins, particularly silver dirhams were found too, unlike gold dinars, which were too valuable for the internal market (ibid.: 42). Little usability of valuable gold coins can be explained by the fact that their value was too high in relation to commercial needs. A way to deal with an exchange of valuable coins was cutting them into pieces. Many treasures were found in fractions: halves or quarters and even smaller parts of the coins.

However, not only the value of gold or the value of money as a medium of exchange counted for our ancestors. The coin as a thing which has purchasing power was also the subject of magic. In many cultures mysterious traces of belief in the power of coins survived: they could heal, protect against the dangers and diseases, hush crying children ${ }^{2}$ (Kiersnowski 1988: 53), provide happiness and success for people, especially young families. This kind of perception of coins was reinforced because of the images appearing on them: having the practical importance and bringing prestige to the rulers or towns, having magical powers to give protection to their users. Far from their place of manufacture, the incomprehensibility of the images and symbols on them grew into many far-fetched perceptions about their significance. Apparently in Roman times in the areas inhabited by the ancient Slavs coins with the image of the chariot were born, as evidenced by one text of Tacitus. The practice of hiding a coin (necessarily with the image of the Virgin Mary) in the bride's veil was performed as magic to ensure happiness, prosperity and blessings. As you can see, the ancient magic meets in this point with the newer Christian culture.

Money gave freedom and independence, relief from the troubles of life, provided a daily meal and an overnight stay, and even entertainment in the form of music and dance, and allowed one to enjoy the popular stimulants, such as tobacco or vodka. Silesian folk tales are taken as an example in this article

2 This applies to coins with an image of cross, produced in the city of Hall in Swabia in the $13^{\text {th }}-14^{\text {th }}$ century. 
- they are full of images of heroes gaining access to inexhaustible sources of money. The magic hen lays golden eggs; alternatively, there could be a golden coin hidden inside each of them. A donkey excretes golden coins, and - in a milder version - spits them out. Gold ducats fall from a trembling lamb or from the grinding mill:

Ojciec mój ma w swym skarbcu czarodziejski mtynek. Jeżeli zakręcisz nim $w$ prawo, posypia się z niego najwymyślniejsze potrawy; jeżeli zakręcisz $w$ lewo posypia się same złote dukaty. Ale musisz zawsze pamiętać o jednym: mtynek będzie hojny tylko wówczas, gdy będzie stużyt ludziom potrzebujacym pomocy.

My father has a magic mill in his treasury. If you turn it right, it sprinkles the most elaborate dishes; if you turn it left, only golden ducats will fall out. But you must always remember: the mill will be generous only if it serves people in need. (OndrGod: 255)

A dumb devil brings large amounts of money, and the wise man is able to cheat him. Also, chests full of gold and precious stones are waiting for daredevils who are not afraid of robbers or dark forces guarding hidden treasures. This is the fairy tale, where a magic ring supplies huge amounts of golden coins:

Jeśli mnie puścisz wolno i już nigdy w tym morzu ryb towić nie będziesz, dam ci w nagrodę czarodziejski pierścień. Kiedy ten pierścień włożysz na palec, oto sto błyszczacych dukatów posypie się z niego na ziemię. Kiedy go zdejmiesz z palca, tyle samo złotych monet znów z dźwiękiem posypie się z niego.

I złota ryba rozwarta szeroko swój pyszczek, pokazując Jasiowi złoty pierścionek.

If you release me and never catch fish in the sea any more, a magic ring I'll give you as a reward. When you put this ring on your finger, one hundred shining ducats will sprinkle on the ground. When you take it off your finger, the same amount of golden coins will sprinkle again with a sound.

And the golden fish opened its mouth wide, showing a golden ring to Jaś. (OndrGod: 222)

The same kind of wishful and magical thinking is noticeable in the belief in the mysterious coin called inkluz, which always comes back to the owner, if he remembers to get a penny for change from each transaction. After some time it appears in a pocket or purse, and you could not confuse it with other ordinary coins. Once the rule is forgotten, it would not come back. 
This idea has very distant roots; it was already known in the first centuries $\mathrm{AD}$ in Persia. The name inkluz is derived from Latin inclusus/includere, which means everything that is inside, and is in some way closed. It also refers to ascetics who voluntarily cut off from the world and remained in the confinement for entire life, not seeing anyone or anything, just accepting food through a window in the wall. Inkluz means also a spirit or a magic power contained in a specific object, such as amulet. A coin, especially of foreign origin, containing drawings, inscriptions and strange characters, is perfectly suitable to be an object endowed with mysterious forces. Tales known since the $10^{\text {th }}$ century in many European countries (including Russia, Germany, Denmark, and Spain) evoke the topic of magic coins. Inkluz was gained at the expense of the greatest efforts and sacrifices, even by selling one's soul to the devil. The tragic fate of an eminent Italian physician and philosopher Pietro d'Abano, who lived at the turn of the fourteenth century and was sentenced to death at the stake for witchcraft, testifies to the story that he had such a coin. Several examples of the literary use of words inkluz, inkluza, and even the adjective inkluzowy derived from them, are noted by S.B. Linde in his dictionary (Linde 1951: 207):

Ja myślę, czy inkluza nie ma, którym nęci / I teraz, że sześć w nim się kocha bez pamięci;

Czarodziej pewne mentale noszac, i inkluzy, z pomoca dyabelstw dziwy robi;

Przyznat mi się, i̇̇ ma inkluzę, dla której go żadne nie bierze żelazo.

I wonder, if he has any inkluz that he entices (ladies) with / Now that six of them are passionately in love with him (Zabłocki, Fircyk w zalotach, 'Dandy in courtship');

A wizard wearing some metals and inkluzes works magic with the devil's help (Zabłocki, Amfitrion, 'Amphitryon');

He admitted to me that he has inkluza, thanks to which he has been immune to iron (sword) (Bohomolec, Komedie, 'Comedy').

It is preceded by the definition of matter, strongly emphasising the evil, dark forces that govern inkluz: "a putative spirit or enemy who helps superstitious people locked in one tool”. Stownik warszawski (Karłowicz et al. 1952: 94) defines it similarly, but includes in the definition the concrete meaning - an enchanted coin: "an object which is inhabited by the evil spirit that helps superstitious people; fairy coin". Here we find the same quotes as in Linde, enriched only by a citation from Zygmunt Kaczkowski's novel "Mąż szalony" ("Crazy man"): 
Za kupione przez siebie towary $i$ bydto ptacit inkluzami, które z cudzych kalet same wracaty do niego.

He paid for goods with inkluzes which later returned to him from the purses of the others.

The link "Inkluzowy: see Pieniądz I." unfortunately leads nowhere, which is one of numerous errors in the dictionary. Doroszewski's dictionary (Doroszewski 1964: 209) cited the quotation of Maria Konopnicka ("Pan Balcer w Brazylii", "Mr. Balcer in Brazil") and Henryk Rzewuski ("Pamiątki Soplicy", "Gift of Soplica"). Doroszewski's definition stresses the importance of inkluz as an amulet, and only one of them can be magic money. In fuller and slightly more objective definitions brought by Michał Arct's "Słownik ilustrowany" from 1929 (Arct 1929: 209), the term denotes "A putative spirit, locked in an object and supposedly bringing good luck to the owner of that object; magic money which when released comes back to the owner".

An extensive explanation of the nature of inkluz is found in Gloger's encyclopedia (Gloger 1978: 272-273):

[...] inkluzem nazywano mniemanego ducha, zamkniętego w jakimś przedmiocie czy narzędziu, monecie czy orzechu podwójnym, i przynoszacego pomoc ludziom zabobonnym. Inkluzami nazywano pewne metale, które noszono jak talizmany przy sobie dla szczęścia. Byt to np. pieniądz, który swemu panu pieniądze sprowadzat, a puszczony do ludzi, powracat $z$ innymi pieniędzmi. [...] Kartowicz przypuszcza, że to znaczenie talizmanu przyczepiliśmy sami nie wcześniej, jak w XVIII w., Linde bowiem nie przytacza dawniejszych autorów.

Inkluz was called a putative spirit, enclosed in an object or tool, coin or double-shelled nut, bringing help to superstitious people. Also certain metals, which were worn as talismans for luck, were called inkluz. It was for example a coin which brought money to its master, and when given to other people, returned with other money. [...] Karłowicz thinks that the meaning of "talisman" was added not earlier than in the eighteenth century, because Linde does not cite earlier authors.

The dictionaries of Reczek (1968), Mączyński (1973) and Knapski (1621) do not include the headword inkluz and this may indicate that there is either not a very long history of belief in the inkluz in Polish society, or a conscious concern of dictionary writers not to spread harmful superstitions that contravene religion is at work here, or finally, that the name of Latin origin inkluz spread relatively recently, while the concept might have been known much earlier. Meanwhile, 
in folk tales inkluz appears as a part of the desired world, similarly to fern blossoms fulfilling wishes or tablecloths and tables filling themselves with food.

Sometimes inkluz in the form of a magic coin did not function in that way, as it was too clearly associated with theft. Here is a story that shows what inkluz looks like in a fairy-tale version, given as a gift to a poor miner by Pustecki (also known in other tales as Skarbnik (Treasurer)), the spirit of the underground mine:

Francek się wzbraniat $i$ nie chciat przyjąć pieniędzy, ale Pustecki $z$ uśmiechem wsypat swe talary do kapelusza Fukaty. Ostatni talar też potożyt Franckowi na dtoni i rzekt:

"Ten talar, Francku, ma czarodziejska moc. Schowaj go oddzielnie i strzeż jak oka w głowie. Gdy bieda ci dokuczy, albo gdy będziesz chciat pomóc drugiemu, to połóż ów talar na swej dtoni, pomyśl ile pieniędzy ci potrzeba, a potem wypowiedz takie zaklęcie:

"Talarku, srebrny talarku, daj mi pieniędzy w podarku!”

A czarodziejski talar $w$ mig spetni każde twe rozumne życzenie. Tylko biada ci, Francku, gdybyś się chciat w ten sposób wzbogacić! Wówczas talar utraci swa czarodziejska moc.”

Po tych stowach Pustecki zniknąt $i$ nigdy się już więcej nie pokazat Franckowi.

Odtąd zmienito się życie u Fukatów. Francek za zarobione z Pusteckim pieniądze zbudowat nowa chatupę. Bieda po zburzeniu starej lepianki wyniosła się gdzieś precz i dała spokój Fukałom. A czarodziejski talar nieraz pomagat potrzebujacym wsparcia sasiadom.

Francek kept refusing to accept money, but Pustecki with a smile poured thalers into Fukała's hat. He put the last thaler on Francek's hand and said:

"This thaler, Francek, has a magic power. Put it separately and guard it as the apple of your eye. When poverty catches you, or if you want to help someone, then put this thaler on your hand, think how much money you need, and then say this spell:

"Thaler, silver thaler, give me money as a gift!"

The magic thaler will fulfill your every reasonable request at once. Only woe to you, Francek, if you wished to become rich that way! The thaler will then lose its magic power."

After these words Pustecki disappeared and would never appear to Francek any more. Since then, life has changed in Fukałas' home. For the money earned with Pustecki, Francek built a new cottage. After the destruction of the old hut, poverty went away and left Fukałas alone. The magic thaler often helped neighbours in need. (OndrGod: 148-149) 
This last thaler is the one which (if money was divided between two employees) turned out to be the odd, the last one, and Francek honestly wanted to give it to his companion, rather than take it for himself. Because he was not greedy, he gained the whole gold, plus the magic thaler, which, as it happens in fairy tales full of didacticism, must be used in moderation and always serve a good cause, supporting other people, rather than make only the owner rich.

Another variation of the magic coin is in a fairy tale about a mysterious person, a woman, who does not refuse to be the godmother to a little girl born in a very poor family. She puts a coin in the child's diapers. After returning home from the church, the mother of the child

[...] todwinęta ty pieluchi i tyn dwureńszczok wypod. Co jedyn podniesta, to ich byto więcej.

[...] unwrapped the diapers and the coin (dwureńszczok, 'two florens') fell out. Whenever she picked one up, there were others. (MalPow: 58)

As you can see, regardless of the mode of action, inkluz has the ability to multiply, thus providing poor people with an inexhaustible source of necessary goods. It should be noted that, as in other tales, the virtue of moderation is strongly emphasised; the magic dwureńszczok allows only the money to raise a child, and also to earn the respect of neighbours.

Having a lot of money in Silesian tales is associated with negative features of character. A rich man is usually selfish and stingy, willing to do harm to others, using their goodwill and naïvety. The soul of a rich man, especially the one who owes money due to gambling, soon becomes a prey for the devil:

Ale toż ty karty wygrowot. Potym juz aji krziwdym drugim robit, a ze godnie pulyrowot za ty wygrane piniondze. Toz Panu Krystu sie to nie podobato. No i potym juz bardzi diabot miot do niego prawo.

But he won at cards. Then he also did harm to others, and spent his winnings for revels. Lord Christ didn't like it. Well, then devil had more right to him. (KadGaw: 228)

The harm done to poor people, even if it is not directly the fault of the ruler - as in this case - necessitates a kind of punishment: things gained through the exploitation of the people reveal the story of their origin, and do not allow wrongdoers to sleep peacefully, but act as a voice of conscience:

Nó i tak potym miała stóżbym ta ksiynżno i kozała, aż ta stóżba jidzie zwónić na tym zwónie. Toż tyn zwón zwónit, że za pinióndze mie kupiono, które z biydnych zedrzóno a z ludzi krziwdy a to wszecko. Tak jakosi była 
ta zwrotka. I że ta ksiynżno nie byta zło, jyny ci dworzanie jeji strasznie drziłi ty podatki, daniny a wszecko możne - dlo tej ksiynżny. Łona że jich rozpyńdziła na sztyry strony, widzom no. A potym że dziepro naprawiła tom krziwdym tym ludziom i że zwón zwónił już potym jinaczi. Jak ale potym zymrziła, tak jak ji chcieli zazwónić tostatni roz, zwón pynknyt i takowy kóniec.

Then the princess had the servants and she ordered them to go and ring this bell. So the bell that was bought for money taken from poor people rang and all of this was due to injustice. This stanza went more or less like that. And the princess was not evil, but her courtiers terribly snatched taxes, levies and everything they could - for this princess. So she drove them out, you see. And then she made amends to the people and the bell rang differently after it. But when she died, and they wanted to ring the bell for the last time, the bell cracked and that's the end. (KadGaw: 214)

Like many other details of morals contained in the Silesian folk tales, such beliefs have probably a lot in common with the harsh reality that the people experienced every day when the ruthless decisions of people in power had left the poor masses with nothing to live on. Ewa Maleczyńska writes:

Już $w$ pierwszej połowie XV w. w obliczu postanowionej przez rade wroctawska zmiany monety, przynoszacej duża korzyść radzie, a klęskę warstwom uboższym, pojawit się na murach domów Wroctawia wcale niewybredny wierszyk:

Bogacze gęby sobie napychaja,

Niszcza biedaków zupetnie,

$Z$ groszami pożeraja niejeden zastaw.

Temu, co robi takie zmiany,

Niech diabet $w$ dzień $i$

W noc na jego kapelusz ...

Already in the first half of the fifteenth century, when the council in Wrocław decided to change currency which would bring great benefit to the council but be a disaster to the poor, quite an unrefined rhyme appeared on the walls of Wrocław's houses:

Wealthy men stuff themselves with food,

Completely destroying the poor, they devour pledges even to a penny.

Who makes such changes,

Let the devil in the day and

Night ... onto his hat. (Maleczyńska 1973: 106-107) 
The effects of such decisions were sometimes tragic:

... w r. 1513 powiesiła się we Wroctawiu z nędzy kobieta z dwojgiem dzieci, która straciła cały majątek na zmianie waluty. W roku 1582 popetnit samobójstwo krawiec nie mający 3 talarów na zapłacenie czynszu.

... in the year 1513 in Wrocław, a mother to two children hanged herself because of her misery, having lost her entire fortune due to currency change. In 1582 a tailor who did not have three thalers to pay for the rent committed suicide. (ibid.: 109)

Fraud and ill-meaning people, who are seen as a dark, thoughtless crowd, are almost a necessary feature of various fairy "masters":

A tuni byli na tym korytarzu, a ton wyliczit ty sztyry tysiónce jakichś tych piniyndzy, a potym se myślot tak: "Taki gupi chamy, tak mi to tacne zrobili. Nie rozumieli ani kontraktu, ani nic. Guwno bedóm rozumieć aji pinióndzóm”. I sto jakichsi tych piniyndzy, niby ryńskich, zebrot, a na kupkym to pozgrabowot, a zawołoł jich, a: "No pójcie zebrać se pinióndze." And they were in the corridor, and he counted out four thousand pieces of the money, and so he thought: These foolish brutes, they did it for me so readily. They did not understand the contract or anything. Just the same they would not understand money. And he took a hundred of this money, in florens, and the rest he gathered on a heap and called them: "So, come and take your money." (KadGaw: 150)

Decidedly negative is the fairy tale image of money-grubbers, whose common feature is that, in principle, they are better off than the people around them, but they don't know how to enjoy what they have, to be content with what they have:

Po krótkiej chwili stały obok ścieżki dwa petniusieńkie worki złotych pieniędzy. Szkoda, że gazda nie zabrat z domu trzeciego wora, bo na ziemi pozostało jeszcze kilka garści monet - Co zrobić? Za nic w świecie nie pozostawi tutaj ani jednego złotego pienią̇ka. Tych kilka garści jeszcze jakoś zabierze. Napetni nimi kieszenie i przestronne cholewy wysokich butów, pasek mocniej zaciągnie i resztę wsypie za koszulę.

I tak zrobit.

Wszystkie pieniądze pozbierat, nawet paluchami pogrzebat $w$ ziemi, czy tam przypadkowo jeszcze coś nie pozostało.

After a short while, two bags full of gold stood next to the path. It is unfortunate that he did not take the third sack from the house, because a few handfuls of coins were left on the ground. - What to do? Not for the entire world will he leave a single penny behind. He'll take somehow the 
few handfuls. He'll fill his pockets and high boots, buckle his belt tighter, and the rest he will put into a shirt.

And so he did.

All the money was gathered up, he even stuck his fingers in the ground, to check if there was accidentally something else left out. (OndrGod: 210)

Of course, greedy people do not have to wait long for justice to happen:

Za jej chciwość i zachtanność spotkała ja zastużona kara. Swoich bogactw miała pod dostatkiem, a jeszcze pragnęta złota, złota i złota. Całe życie chciała się pławić $w$ złocie, dlatego zaklątem ja $w$ złoty posag.

For her greed and cupidity she was deservedly punished. Her wealth was plentiful, but she still wanted more gold, gold, and gold. All her life she wanted to wallow in gold, and therefore I cast a spell on her and turned her into a gold statue. (OndrGod: 46)

Greed is evaluated negatively (see also Kalda 2013: 217, this volume, about greedy treasure hunters), so the hero of a tale that aspires to get a great treasure needs to be warned that he may take only as much as he really needs:

Tam, pod ściana w gtębi jaskini, stoją kopiaste kadzie złotych dukatów. Jeżeli jesteś $w$ potrzebie, to idź i nabierz ich tyle, ile ci potrzeba. Biada ci jednak, jeżeli żadza złota omamiła twoje serce, a usta nastroiła do kłamstwa. Wówczas dla ciebie nie będzie ratunku ani zmitowania.

There, by the wall in the depths of the cave, stand vats full of gold ducats. If you are in need, then go and take as many as you need. Woe to you, however, if the lust of gold bewitched your heart, and lips tuned to lie. Then, there will be no help or mercy for you. (OndrGod: 207)

Having a lot of money is in fact dangerous: lack of sensitivity to the suffering of others causes pride and selfishness. It lets us just arbitrarily decide about the fate of the others, but even - in a sense - to buy them as people.

A potym dat matce jei sześć dukatów, że se jedne córke (jedno dziewczę) weźnie, jak pójdzie na spadek ('z powrotem').

And then he gave their mother six ducats to take one daughter (one girl) when he goes back. (MalPow: 5)

This is not, unfortunately, only the fairy reality: history brings more than enough evidence that such cases actually occurred, and not in very distant times. Even stories from the nineteenth century tell us how in times of poverty,

${ }^{3}$ I am replacing here the semi-phonetic notation, used by Lucjan Malinowski with orthographic notation, while still trying to save dialectal features of the original text. 
families with many children just sold a few children "for export", for example to the U.S., because they were not able to feed them all.

Jak roz prziszły ty gtodne roki, to od nas z Jistebnego jechali furmanio aż do Uher po kukurzice a nic nie przywiyźli. To mój starek jak wrócit du dóm, to piniądzami rznąt o stót a rozpłakot sie, bo dzieci chciaty jeść. Każdy byt rod jak jaki to dzieciacko umrzito, bo nie chciało już jeść. Wtedy - pamiyntóm - miałach sztyry abo piyńć rokóf, jeździli tacy agyncio od morza po Jistebnym i kupowali od tych biydnych ludzi dziecka do Hameryki a potym jich na wozie odwożali. A ty dziecka strasznie ptakaty a pytaty tych ojców, aby jich nie sprzedowali. Mje też niboszczyk tata chcieli tym agyntóm sprzedać, bo dóma nie byto co jeść, ale jo tak żatośnie płakała a po ziymi sie kulata, aż nieboszczka mama sami sie nadymna slitowali $i$ nie dali mie sprzedać ${ }^{4}$.

Once, when the years of famine came, carters from Istebne went as far as to Uher to buy corn, but they brought back nothing. So my grandpa, when he came home, threw money on the table and burst out crying, because children were hungry. Everybody was happy when one child died, because then it was hungry no longer. This time - I remember - I was four or five years old, some agents travelled from the sea till Istebne and bought children from the poor people to take them to America; they took them on a cart. And the children cried terribly and asked their parents not to sell them. And my departed dad wanted to sell me too to these agents, because there was nothing to eat at home, but I cried so woefully and rolled around on the ground, that my late mom took pity on me and didn't let him sell me.

Even the death of a child in families with many children was sometimes desirable, although this is incredibly cruel:

Gazda tam nie byt wielkim, miot jyny stara chatupe a pola ledwo na dwie krowy, ale za to miot dwanościoro dziecek a wszystki mu jako na złość $\dot{z} y t y$, a żodyn nie chciot umiyrać.

He was not a great farmer, he had only an old cottage and a field for two cows, but he had twelve children and all of them were alive to make matters worse, and no one wanted to die. (PiegSęk: 127)

So both the excess money and its absence seemed to be a supernatural phenomenon, planned by higher and dark forces, which man did not control.

4 “Zwrot" 1952, Vol. 8-9, p. 11. 
Sometimes, however, the hero of these stories deliberately evokes the dark forces to protect their property against possible attempts of theft:

Tobie, zły duchu, oddaję w opiekę moje pieniądze. Ty je strzė̇ tak dtugo, dopóki tych pieniędzy ktoś nie wyorze drewnianym pługiem zaprzężonym $w$ dwa koguty, wylęgte $z$ jednego jajka.

I entrust my money in your care, evil spirit. You guard it as long as someone ploughs it up with a wooden plough drawn by two cockerels hatched from one egg. (OndrGod: 202; for similar examples, see also Kalda 2013: 224 , this volume)

Due to its absurdity the applied spell seems not to be possible to overcome, but one poor man persistently bears with all difficulties and finally wins the enchanted treasure. Money remains the domain of infernal powers even if the poor and needy manage to get hold of it. Their appearance is usually accompanied by unnatural phenomena, images and sounds:

Las strasznie zaszumiot, kamiynie spadowaty skónsik z góry, jedle sie tómaty, aż naroz skała sie totwarta, a z ni wysypaty sie same złote dukaty.

Matka z ceróm wartko grabity złoto do fortuchów.

The forest whispered terribly, stones fell down from somewhere, fir trees broke, and all of a sudden a rock opened and gold ducats poured out of it.

Mother and her daughter rapidly gathered gold into their aprons. (OndrŚl: 70)

However, knowledge about what security measures should be taken against the evil (a circle drawn with holy chalk), and additional protective effect of church bells makes gaining wealth from hell much easier:

Niedaleko Djobligo Mtyna zatoczyty świyncónóm krejdóm togrómne koło. Siadty se potym $w$ postrzodku tego kota i czakaty. Naroz, jak w Jabłónkowie zaczły zwónić zwóny, tustyszały pod ziymióm jakisi gtuchy brzynk i tu niedaleko nich, na matej kympce, wyskoczyt ze ziymie kotlik petny złotych dukatów.

Not far from Evil Mill they have drawn a huge circle with the holy chalk. Then the two women sat down at the center of the circle and waited. Suddenly, when bells began ringing in Jabłonków, they heard a dull clang from under the ground and then not far from them, on a small hillock, a pot full of gold ducats jumped out of the ground. (OndrŚl: 69) 
The money having its source in the world of dark forces is somehow "tainted" by the curse of their origin. Here is good advice for a man who is going to hell to sell sausage:

“Wiem, dokąd śpieszysz!” rzekt starzyczek. "Nie bierz ty jednak od diabtów za jelita pieniędzy, bo diabelskie dukaty nie przyniosq ci szczęścia. Chciej od nich tylko serwetkę z trzeciego stotu."

"I know where you are going!" - the old man said. "Don't take any money from the devils for the sausage, because the devil's ducats will not bring you happiness. Take only the third table napkin from them." (OndrGod: 182)

In more contemporary Silesian stories, caution towards such money is still recommended:

Wszystkie dzieci ze szkoty przichodzity ku “'̇abce”, żeby im te piniondze od utopka pokozot, ale żodyn ich niy chciot pomacać, bo bezmata się potym człowieka piniondze niy trzimiom.

All the children from school came to "Żabka" ('The Frog') to see the money from the water spirit, but nobody wanted to touch it, because apparently that money burned a hole in peoples' pockets. (DzierżU: 30)

The stories explain also, using religious arguments, why Satan loses his power over money on particular occasions.

Kiejsika we Wielki Pióntek szła baba ze swoim synkym do kościoła. No a jako to stare legyndy powiadajóm, że we Wielki Pióntek diabot przestanie mieć moc nad pinióndzami za to, że Judasz Pana Krysta zaprzedot za pinióndze.

Once on Good Friday a woman was walking with her son to church. And, as the old legends said, on Good Friday Satan doesn't have power over money, because Judas sold Lord Christ for money. (KadGaw: 341)

Only donation of evil money for religious and charitable purposes can remove the curse from them. So the heroes of the treasure stories should build and equip churches and chapels, help needy neighbours and must not forget about alms for the poor.

I trzi tysiónce z tych wygranych piniyndzy dót jim na tyn kościótek, $i$ biskup puścit stóżbym, i po kumedyi.

And three thousand of his money he gave to the church, and the bishop let the servants free, and that's the end of the story. (KadGaw: 173) 
The attitude towards money as a terrible force fits the stereotypical image of the rich Jews living in Silesia as well as in other areas of Poland. The Jew of the stories is the wealthiest man, as well as ruthless, and alien to the natives racially, linguistically and religiously. Many varied Silesian stories tell for instance how a Jew sues somebody, and of course loses the case because of his own stupidity and inability to speak Polish, and the defendant in the trial manages to avoid liability. Sometimes the robbed Jew tries to pursue his rights in a court of law, but ultimately is duped and incurs still additional costs, which is to be an expression of a particular justice, because the Jew in fairy tales is never poor. This is related to the general belief that Jews are wicked and unjust, as in the following stories:

Byt jedyn biydny chtop. No toż biyda go cista na wszecki strony i pojczot tod Zida siedym ryńskich. Ale tyn Zid też jeszcze kazowoł cosi łodrobiać tymu chtopu i to. Chłop łodrobit też tych siedym ryńskich, ale jak prziszet po rachunek, Zid fort chciot jyny siedym ryńskich.

Once upon a time there was a poor peasant. He lived on the breadline and once borrowed seven florens from one Jew. And the Jew ordered him to work off that money. The peasant worked off those seven florens, but when he came to receive a confirmation that the debt was worked off, the Jew still wanted his seven florens back. (KadGaw: 186)

Folk stories about how Jesus walked the world in the company of saints and put into practice the Gospel truths often confront the merciful and noble figure of Christ with the fierce and greedy Jew:

Ja, Pón Krystus ku zgorszyniu Żida powiedziot, że łaska bosko za pinióndze się nie sprzedo, że tun nie chce nic. I tyn Żid hrómsko zły byt na Pana Krysta, że tak pinióndze się cisnóm do kapsy. a że łon jich nie chce wziónć.

So, Lord Christ, to the Jew's horror, said that divine grace will not be sold for money, that he does not want anything. And the Jew was terribly angry with Lord Christ that the money is there for the taking, and he doesn't want to take it. (KadGaw: 124)

They also carry the implicit explanation of why the Jews have no share in Christ's salvation. Of course, the money is the cause of everything:

Pón Krystus prawi: "Zidzie, stóż ty pinióndze haf. Podzielimy się równym dziołym," widzom no. A tyn Żid się pyto: "Panie, no dyć nas je jyny tela. Dlo kogóż ta kupka jedna będzie?” Pón Krystus powiedzioł tela: “Ta kup- 
ka drugo będzie ku tej piyrszi, gdo tyn kołocz zjod, jak my szli przez tom pustyniym.” Jak ale to Pón Krystus wyrzyk, Żid wyskoczit: “Jak Boga kocham a wszeckich świyntych, Panie, jam zjad, jam zjad, jam zjad." I Pón Krystus że mu dót ty dwie kupki a kopnyt mu do rzici, a że tod tego czasu ze Żidzi majom pinióndze, jyny że tudziału w królestwie niebieskim że ni majom.

Lord Christ said: "Jew, put the money here. We will share it equally," you see. And the Jew asked: "Lord, but there are only two of us here. Who is the other pile for?" Lord Christ said: "This second one will go to the person who ate the cake as we walked past him in the desert." When Lord Christ said that, the Jew blurted out: "I swear to God and all the saints, Lord, I ate it, I did, I did." And Lord Christ gave him these two piles and gave him a kick, and from this time Jews have money, but haven't got a place in the kingdom of heaven. (KadGaw: 127)

Many Silesian folk tales show a rather ambiguous attitude to the ownership of money. On the one hand, money provides the means to live, and is therefore particularly desired; therefore, its magic variety appears in fairy tales, which gives a sense of security to the holders of treasure. On the other hand, the complete lack of money, as well as its excess, evokes morbid desires in people, which compels them to hurt others and disregard anything outside their own benefit. It is impossible not to notice that this way of perceiving and evaluating money has not changed notably over the centuries, including the present times. The ancient authors already warned: "To what extremes / Will you not drive the hearts of men, accurst / Hunger of gold!" (Virgil 1992: 67).

\section{References}

Arct, Michał 1929. Stownik ilustrowany języka polskiego [Illustrated dictionary of the Polish language], Vol. 1. Warszawa: Wydawnictwo M. Arcta.

Doroszewski, Witold (ed.) 1964. Stownik języka polskiego [Dictionary of the Polish language], Vol. 3. H-K. Warszawa: Państwowe Wydawnictwo Naukowe.

Gloger, Zygmunt 1978. Encyklopedia staropolska ilustrowana. [Illustrated dictionary of Old Poland.] Vol. 2. Warszawa: Wiedza Powszechna.

Grimal, Pierre 1987. Stownik mitologii greckiej i rzymskiej. [Dictionary of Greek and Roman mythology.] Wrocław-Warszawa-Kraków-Gdańsk-Łódź: Zakład Narodowy im. Ossolińskich. 
Kalda, Mare 2013. Hidden treasure lore in Estonian folk tradition. In: L. Laineste \& D. Brzozowska \& W. Chłopicki (eds.) Estonia and Poland. Creativity and tradition in cultural communication, Vol. 2: Perspectives on national and regional identity. Tartu: ELM Scholarly Press, pp. 213-230.

Karłowicz, Jan \& Kryński, Adam \& Niedźwiedzki, Władysław (eds.) 1952. Stownik języka polskiego. [Dictionary of the Polish language.] Vol. 2. H-M. Warszawa: Państwowy Instytut Wydawniczy.

Kiersnowski, Ryszard 1988. Moneta w kulturze wieków średnich. [The coin in the Middle Ages.] Warszawa: Państwowy Instytut Wydawniczy.

Kiersnowski, Ryszard 1962. Poczatki pieniadza polskiego. [The origins of the Polish currency.] Warszawa: Wiedza Powszechna.

Knapski (Cnapius), Grzegorz 1621. Thesaurus Polono-Latino-Graecus (...). Cracoviae.

Kopaliński, Władysław 2000. Stownik wyrazów obcych i zwrotów obcojęzycznych z almanachem. [Dictionary of foreign words and phrases in almanacs.] Warszawa: Świat Książki.

Krawczuk, Aleksander 2005. Wielka historia świata. Vol. 3: Świat okresu cywilizacji klasycznych. [General history of the world. Vol. 3: The classical period of civilisation.] Kraków: Fogra Oficyna Wydawnicza.

Linde, Samuel Bogumił 1951. Stownik języka polskiego. [Dictionary of the Polish language.] Vol. 2. G-L. Warszawa: Państwowy Instytut Wydawniczy.

Maleczyńska, Ewa 1973. Życie codzienne Śląska w dobie odrodzenia. [Everyday life during the Silesian revival era.] Warszawa: Państwowy Instytut Wydawniczy.

Mączyński, Ioannis 1973 [1564]. Lexicon latino-polonicum (...), Regiomonti 1564. KölnVien: Böhlau Verlag.

Reczek, Stefan 1968. Podręczny stownik dawnej polszczyzny. [Handy dictionary of Old Polish language.] Wrocław-Warszawa-Kraków: Zakład Narodowy im. Ossolińskich.

Virgil 1992. The Aeneid. Translated by Robert Fitzgerald with an Introduction by Philip Hardie. Everyman's Library. London: David Campbell Publischers Ltd.

Zwrot. Miesięcznik kulturalno-spoteczny. [Turnaround. Monthly journal of cultural and social issues.] 1952, Vol. 8-9. Czeski Cieszyn: Wydawnictwo Polskiego Związku Kulturalno-Oświatowego w Czechach, p. 11. 
Małgorzata Iżykowska

\section{Sources}

DzierżU = Dzierżawa, Bogdan 1995. Utopek z Wielopola [Utopek of Wielopole]. Żory: Drukarnia "Oldprint".

KadGaw = Kadłubiec, Karol Daniel 1973. Gawędziarz cieszyński Józef Jeżowicz [Storyteller Józef Jeżowicz]. Ostrava: Profil.

MalPow = Malinowski, Lucjan 1900. Powieści ludu polskiego na Ślasku [Stories of the Silesian people]. Kraków: Akademia Umiejętności.

OndrGod = Ondrusz, Józef 1977. Godki śląskie. Podania i baśnie ze Śląska Cieszyńskiego [Stories from the Silesian basin]. Ostrava: Profil.

OndrŚl = Ondrusz, Józef 1963. Śląskie opowieści ludowe [Silesian folk tales]. Ostrava: Wydawnictwo Okręgowe.

PiegSęk = Piegza, Karol 1979. Sękaci ludzie [Sękaci people]. Ostrava: Profil. 